\title{
Brazilian scientific production in periodontics: a national panorama from a bibliometric study
}

\author{
Diego Soares ${ }^{1 *}$, Monicky Maciel ${ }^{2}$, Altamir Figueiredo-Filho ${ }^{3}$, Jéssica Melo ${ }^{4}$
}

\author{
1. Professor of dentistry, Faculdade de Integração do \\ Sertão (FIS), PE, Brazil. \\ 2. Dentistry student, Faculdade Uninassau Caruaru, \\ PE, Brazil. \\ 3. Department of dentistry, Universidade Federal de \\ Pernambuco (UFPE), PE, Brazil. \\ 4. Student of the post-graduate program in dentistry, \\ Universidade Estadual da Paraíba (UEPB), PB, Brazil \\ * Corresponding Author: Diego Moura Soares | \\ Department of Dentistry Faculdade de Integração \\ do Sertão - FIS | Endereço: R. João Luiz de Melo, \\ 2110 - Tancredo Neves, Serra Talhada - PE, 56909- \\ 205 | Phone-Fax: +55 (081) 3721-1209 | Email: \\ diegomsoares@gmail.com \\ Work received on 10/12/2018. \\ Approved for publication on 19/12/2018
}

\begin{abstract}
Objective: The objective of this study was to conduct a bibliometric analysis of periodontal research done in Brazil. Methodology: This study was developed by examining papers published at the 2017 Annual Meeting of the Brazilian Society of Dental Research (SBPqO). Summaries related to the field of Periodontics have been evaluated. An Excel spreadsheet with details of institutions, funding agencies, states, regions, subjects, and types of research methods was collected. Descriptive and analytical statistics were used to perform the analysis. Results: 3,095 articles were published in the annals of 2017 SBPqO. Only $216(6.97 \%)$ articles dealt with issues related to Periodontics. The Southeast Region accounted for $66.7 \%$ (144 papers) of all published papers. More than half of the studies (64.8\%) were about basic periodontal therapy and $48.6 \%$ (105 papers) received some sort of funding. Conclusion: The Southeast Region had the highest academic production. Public institutions were leaders in research activities, and basic periodontal therapy was the subject with the highest number of published papers. KEY WORDS
\end{abstract}

Periodontics; Dental research; Bibliometrics.

Rev. Clin. Periodoncia Implantol. Rehabil. Oral Vol. 12(2); 66-69, 2019.

\section{INTRODUCTION}

The progress of scientific knowledge improves the quality of life of human beings. Nations who do not participate in scientific activities and, consequently, those who do not engage in scientific researches tend to live outside of modern world standards and experience few improvements in day-to-day life. Finding ways to break inertia and achieve sustainable development is one of the great challenges of humanity today ${ }^{(1)}$.

In Brazil, scientific research has gradually increased in the last decades, following a worldwide trend. Brazilian scientific production has improved on the world stage, placing it among the 25 most productive countries in the world ${ }^{(2,3)}$. In Dentistry, Brazilian scientific research is one of the most developed and widely respected in the international scientific community. In 2012, Brazil ranked second in the world scientific production ${ }^{(4)}$.

The increase of scientific researches in the dental area is due to the new curricular model used in the Dentistry course- adopted in most of the Brazilian higher education institutions - that encourage the practice of research activities. It aims to prepare the future student with required academic, professional, and contemporary skills to work in the Unified Health System (SUS, in Portuguese) $)^{(5)}$. Thus, public and private education institutions are mainly responsible for the progress of research activities in the country ${ }^{(6)}$.

Some studies have conducted a survey of the scientific output in Dentistry done in Brazil in recent years, in order to know the profile of this production. Researches in areas related to technical and traditional disciplines in Dentistry have decreased; meanwhile, it has been observed an increased attention in basic areas and new Dentistry specialties(7).

Bibliometric research has a fundamental role in the analysis of scientific production since its indicators portray the degree of development of a specific scientific field ${ }^{(8)}$. Bibliometric analysis seeks to evaluate scientific production using methods that measure the productivity of researchers, groups or institutions $\mathbf{s}^{(9,10)}$

There are several studies that seek to outline the state of the national dental research based on specific events, such as the $\mathrm{SBPqO}^{(6,7)}$. The SBPqO is the Brazilian division of the International Association of Dental Research, and its annual meetings - promoted since 1983 are considered the largest and most important event of researches in Dentistry conducted in the country(11). These meetings present studies from all over Brazil; as a result, it can be considered a representative sample of Brazilian dental research done today.

Such studies aim to outline the profile of scientific production based on an examination of specific areas, such as Endodontics ${ }^{(10)}$ and Pediatric
Dentistry ${ }^{(12)}$, or in a specific region of the country, such as the Northeast Region. Studies of this nature show the areas that require more incentive and investment for its development. For example, Pontes et al. (2007) (10) found that there was an increased interest in Endodontics, even on a small scale, and that the academic production was mainly concentrated in certain regions and institutions of the country. In the same way, there is no study that evaluates the academic production in Periodontics in the country, which justifies the relevance of this study.

The Federal Council of Dentistry defines Periodontics as the specialty that aims to study the supporting and surrounding tissues of the teeth and their substitutes. This specialty is responsible for the diagnosis, prevention, and treatment of changes in these tissues, as well as the manifestations of systemic conditions in the periodontium and maintenance therapies for health control ${ }^{(13)}$. Thus, the improvement of diagnostic, preventive and therapeutic techniques in Periodontics is an important issue, considering its relevance for the preservation of dental elements and consequently the quality of life of the general population.

The way diseases are understood changes constantly and this brings benefits to the patients. Hence, therapeutic approaches need to be revised so that methods are up-to-date, and diseases can be eliminated. Gingival and periodontal diseases have been recorded since the dawn of humanity. The adoption of new research methods has helped in the treatment of these diseases. Previously, the periodontal treatment was considered highly aggressive and when carried out, resulted in sequelae for patients. With the improvement of scientific methods and increased knowledge of the etiopathogenesis of periodontal diseases, conservative and effective methods are used for prevention, treatment, and maintenance of periodontal health nowadays.

Therefore, it is necessary to follow the studies conducted on this subject to guide the daily clinical conduct. The aim of this study was to carry out a bibliometric analysis of the studies conducted in Periodontics in Brazil, using the data published in the annals of the $34^{\text {th }}$ Annual Meeting of the Brazilian Society of Dental Research (SBPqO), evaluating the production according to geographical location, type of institution, promotion of research and preferred subjects in Periodontics.

\section{METHODOLOGY}

This article was developed by tabulating scientific papers presented at the Annual Meeting of the Brazilian Society of Dental Research (SBPqO). We examined any paper related to the specialty of Periodontics, one of the 23 fields of specialization in Dentistry. We opted for the survey in the 
annals of the SBPqO because its annual meeting is the largest in Brazil related to the subject, bringing together academics, post-graduates, professors and researchers, according to Cavalcanti (2004)(11).

The data were collected in the annals (summaries of papers accepted for presentation) of the 34th Annual Meeting of SBPqO, held in 2017, in the city of Campinas, São Paulo. The annals are publicly available, for the entire scientific community, shortly after the conclusion of the meetings in the electronic page of SBPqO (www.sbpqo.org.br/resumos/index.asp). Data extraction from those annals was performed from March to April 2018. All abstracts were examined by two reviewers and those who had some connection to the field of Periodontics were included in the study. In the event of any disagreement between two reviewers, a third one was consulted for tiebreakers.

To record the data, a spreadsheet was developed in Excel (2013), Professional Plus version, containing information about the institution where the study was developed, state and region of the country (North Region, Northeast Region, South Region, Southeast Region, and CenterWest Region). We also considered the type of institution - Private, State, Federal or Municipal Autarchy - as well as the periodontal area (Basic Periodontal Therapy, Experimental Periodontitis, Periodontal Plastic Surgery, Pre-Prosthetic Surgery, Periodontal Surgical Therapy, Periapical Therapy, Interrelationship between Periodontics and Other Specialties, and Peri-implant Surgery). In addition, we examined whether there was any form of funding used for the studies and the types of research methods conducted (Observational Research, In Vivo Experiment, In Vitro Experiment, Ex vivo Experiment and Literature Review).

All data were collected by two examiners individually and subsequently compared to one another. The classifications attributed to the studies, such as area of Periodontics and type of research method, were conducted and adapted by the authors based on the information provided in the abstracts

The data collected were based on previously published studies that used similar methodologies ${ }^{(6,11)}$. Statistical analysis was performed using descriptive statistics (frequency distribution) and analytical statistics using the chi-squared test. For the chi-squared test, the variables region, institution, and financing were initially categorized. The analysis was performed in the SPSS program, version 16, and presented as percentage and absolute value. A level of 0.05 was used as the cutoff for significance.

\section{RESULTS}

A total of 3,095 articles were published in the annals of the 2017 Meetings of the Brazilian Society of Dental Research. Only 216 $(6.97 \%)$ studies dealt with issues related to Periodontics. Regarding the geographical location from where the studies were originated, the Southeast Region was responsible for $66.7 \%$ (144 papers) of the national publication, followed by the South Region with $12.5 \%$ (27 papers). Among the states located in the Southeast Region, São Paulo is responsible for $54.6 \%$ (118 papers) of the national publications. The distribution of publications according to the regions and states can be seen in table 1 .

Table 2 shows the distribution of papers according to the type of institution (federal, state, private and municipal autarchy) and region. Research conducted in state institutions accounted for $39.8 \%$ of the national production, with most of them concentrated in the Southeast Region.

Regarding the use of funding for research activities, 48,6\% (105 papers) received some kind of funding. Research Support Foundations (FAPs, in Portuguese) accounted for $52.4 \%$ of the total, followed by the National Council for Scientific and Technological Development (CNPq, in Portuguese) with $20 \%$ (see table 3 ).

Regarding the specialty, more than half of the studies (64.8\%) dealt with basic periodontal therapy. Studies that used experimental periodontitis for tests of new adjuvant therapies were also present (19.5\%). Table 4 shows the distribution according to the field in Periodontics.

With reference to the types of research methods used, $42.6 \%(92$ papers) were classified as observational studies, followed by in vivo experiments with $39.8 \%$ (see table 5 ).

\section{DISCUSSION}

Scientific research is an important tool for science development and the progress of society, including healthcare and Dentistry ${ }^{(11)}$. In 2017, we verified a low scientific attention in Periodontics in Brazil, with only $6.97 \%$ of all papers presented at the $\mathrm{SBPqO}$ meeting in that year being about that subject. Despite this, there was an increased number of papers focusing on Periodontics when compared to the percentage recorded by Cavalcanti et al. (2004) ${ }^{(11)}$. At the 20th SBPqO meeting in 2003, only $3.8 \%$ of papers were related to Periodontics.

The Southeast Region is the one with the highest academic production,
Table 1. Distribution of production according to the Brazilian regions and states.

\begin{tabular}{|c|c|c|}
\hline Region / State & Frequency & $\left(n^{\circ} / \%\right)^{*}$ \\
\hline MIDWEST & 6 & $2,8 \%$ \\
\hline Mato Grosso & 5 & $2,3 \%$ \\
\hline Distrito Federal & 1 & $0,5 \%$ \\
\hline NORTHEAST & 25 & $11,6 \%$ \\
\hline Bahia & 4 & $1,9 \%$ \\
\hline Ceará & 2 & $0,9 \%$ \\
\hline Maranhão & 9 & $4,2 \%$ \\
\hline Paraíba & 1 & $0,5 \%$ \\
\hline Pernambuco & 1 & $0,5 \%$ \\
\hline Piauí & 3 & $1,4 \%$ \\
\hline Rio Grande do Norte & 5 & $2,3 \%$ \\
\hline NORTHE & 14 & $6,5 \%$ \\
\hline Acre & 1 & $0,5 \%$ \\
\hline Pará & 12 & $5,6 \%$ \\
\hline Tocantins & 1 & $0,5 \%$ \\
\hline SOUTHEAST & 144 & $66,7 \%$ \\
\hline Espírito Santo & 6 & $2,8 \%$ \\
\hline Minas gerais & 9 & $4,2 \%$ \\
\hline Rio de Janeiro & 11 & 5,1 \\
\hline São Paulo & 118 & 54,6 \\
\hline SOUTH & 27 & $12,5 \%$ \\
\hline Paraná & 14 & $6,5 \%$ \\
\hline Rio Grande do Sul & 9 & $4,2 \%$ \\
\hline Santa Catarina & 4 & $1,9 \%$ \\
\hline Total & 216 & $100 \%$ \\
\hline
\end{tabular}

with $66.7 \%$, and has São Paulo as the state with most published scientific papers, with $54.6 \%$ of the total. These findings are in line with the conclusions of Pontes et al. (2017)(10). According to the authors, when examining the 2011, 2013 and 2014 SBPqO meetings, specifically the area of Endodontics, they found that the Southeast Region was responsible for $66.1 \%$ of the published academic papers on the subject, and São Paulo was the state with the highest academic production, with $47 \%$ of the total. There are no similar studies carried out in previous years about the scientific production in Periodontics, which makes it difficult to perceive the evolution of academic production in Periodontics in the country.

For decades, there have been developmental disparities among Brazilian macroregions, which are also expressed in the regional distribution of scientific and technological resources, regional training of human resources, and academic production ${ }^{(11,12)}$. It is perceived that the scientific researches made in Brazilian universities located in the Southeast Region are more advanced than those made in other regions of the country. This implies that a greater amount of resources has been destined for those universities in question ${ }^{(10)}$. This is corroborated by the data found in this study, where from a total of 105 researches that received some sort of funding, 69 were carried out in the Southeast Region. This reinforces the need for decentralization of funding resources, since technical and scientific knowledge in Brazil is way more advanced in the Southeast and South regions, and most of the government investments continue to be directed to these regions ${ }^{(11)}$.

We found that the state of São Paulo was the one mainly responsible for the national productions. According to a report on Brazilian research production ${ }^{(14)}$, the University of São Paulo presents the highest production of any Brazilian higher education institution. However, The Rio de Janeiro State University, the largest representative in terms of academic production in the state of Rio de Janeiro, has a greater citation impact, being at the top of the most cited articles in the world, even though it does not present the largest number of published works. This is due to the 
Table 2. Distribution of the papers according to the type of institution (federal, state, private and municipal autarchy) and the region of the country.

\begin{tabular}{|c|c|c|}
\hline Institution & Frequency & $\left(n^{\circ} / \%\right)^{*}$ \\
\hline FEDERAL & 56 & $25,9 \%$ \\
\hline Nordeste & 8 & $3,7 \%$ \\
\hline Norte & 4 & $1,9 \%$ \\
\hline Sudeste & 36 & $16,7 \%$ \\
\hline Sul & 7 & $3,2 \%$ \\
\hline Centro-Oeste & 1 & $0,5 \%$ \\
\hline STATE & 86 & $39,8 \%$ \\
\hline Centro-Oeste & 2 & $0,9 \%$ \\
\hline Nordeste & 10 & $4,6 \%$ \\
\hline Norte & 5 & $2,3 \%$ \\
\hline Sudeste & 60 & $27,8 \%$ \\
\hline Sul & 9 & $4,2 \%$ \\
\hline TOILET & 70 & $32,4 \%$ \\
\hline Centro-Oeste & 3 & $1,4 \%$ \\
\hline Nordeste & 7 & $3,2 \%$ \\
\hline Norte & 5 & $2,3 \%$ \\
\hline Sudeste & 45 & $20,8 \%$ \\
\hline Sul & 10 & $4,6 \%$ \\
\hline MUNICIPAL AUTHORITY & 4 & 1,9 \\
\hline Sudeste & 3 & $1,4 \%$ \\
\hline Sul & 1 & $0,5 \%$ \\
\hline Total & 216 & $100 \%$ \\
\hline${ }^{*}$ Quiquadrado Test & & \\
\hline
\end{tabular}

high engagement in international collaboration and partnership with large international companies that the university presents ${ }^{(14)}$.

Most of the research in Periodontics was performed in public institutions $(39.8 \%)$. These findings reaffirm the hegemony universities located in the Southeast Region of Brazil. Universities such as the University of São Paulo and the State University of Campinas, both of which located in the state of São Paulo, are considered benchmarks in dental research. Morosini et al. (2012)(12) argue that this may be due to the fact that the government is the main sponsor of scientific and technological activities in Brazil. In addition, the Southeast Region receives more funding and has more postgraduate courses at master's and doctoral level, favoring the quantity and quality of the studies performed by those universities ${ }^{(14)}$.

The proximity to the event and travel logistics can play an important role when examining the overwhelming presence of certain regions, such as the Southeast and South Regions, in comparison to others, since the event occurs in the state of São Paulo. In addition, universities from the Southeast and South Regions have a greater number of postgraduate programs, thus increasing the amount of production in the area.

When comparing the production in Periodontics with other specialties, such as Endodontics, we found a lower proportion of studies presented. This can be seen in the study by Pontes et al. $(2017)^{(10)}$ where, when analyzing the studies published in the 2011 SBPqO meeting, they found that $38.1 \%$ were in Endodontics. Likewise, Morosini et al. $(2012)^{(12)}$ attest that $9.06 \%$ of papers presented in the 2009 SBPqO meeting were about Pediatric Dentistry. In the 2017 SBPqO meeting, we found that $6.97 \%$ of studies were related to periodontics.

Observational research was the most performed type of research in periodontics in the $2017 \mathrm{SBPqO}$ meeting, corresponding to $42.6 \%$, followed by in vivo experiments, with $39.8 \%$. These results differ from those found by Pontes et al. (2017)(10), where the authors found that, in Endodontics, experimental research was the most frequent one, with $95.8 \%$ of published papers. This may be related to the fact that most observational studies provide substantial data for a better evidence-based clinical trial. According to Rocha and Xavier (2007)(15), observational studies, whether cross-sectional, retrospective or even medical records, have the advantage of gathering large numbers of patients and, sometimes, offer results closer to reality.
Table 3. Distribution of the works according to the receipt of funding (funding agency) and the region of the country.

\begin{tabular}{|c|c|c|}
\hline Funding & Frequency & $\left(n^{\circ} / \%\right)^{*}$ \\
\hline CNPQ & 21 & $20,0 \%$ \\
\hline Centro-oeste & 2 & $1,8 \%$ \\
\hline Nordeste & 5 & $4,8 \%$ \\
\hline Sudeste & 11 & $10,5 \%$ \\
\hline Sul & 3 & $2,9 \%$ \\
\hline FAPs & 55 & $52,4 \%$ \\
\hline Nordeste & 8 & $7,6 \%$ \\
\hline Norte & 4 & $3,8 \%$ \\
\hline Sudeste & 37 & $35,3 \%$ \\
\hline Sul & 6 & $5,7 \%$ \\
\hline CAPES & 17 & $16,2 \%$ \\
\hline Centro-oeste & 1 & $0,9 \%$ \\
\hline Sudeste & 14 & $13,5 \%$ \\
\hline Sul & 2 & $1,8 \%$ \\
\hline $\mathrm{HEl}^{* *}$ & 3 & $2,9 \%$ \\
\hline Sudeste & 3 & $2,9 \%$ \\
\hline OTHERS ${ }^{* * *}$ & 9 & $8,5 \%$ \\
\hline Nordeste & 4 & $3,8 \%$ \\
\hline Norte & 1 & $0,9 \%$ \\
\hline Sudeste & 4 & $3,8 \%$ \\
\hline Total & 105 & $100,0 \%$ \\
\hline \multicolumn{3}{|c|}{$\begin{array}{l}{ }^{*} \text { Quiquadrado test } \\
{ }^{* \star} \text { Higher education institutions } \\
{ }^{* \star *} \text { Private institutions that sponsored the studies }\end{array}$} \\
\hline
\end{tabular}

Table 4. Distribution of the papers according to the area of knowledge of periodontics.

\begin{tabular}{l|c|c|}
\hline \multicolumn{1}{|c|}{ Area of knowledge } & Frequency & ( $\left.\mathbf{n}^{\mathbf{0}} / \mathbf{\%}\right)$ \\
\hline Basic periodontal therapy & 140 & $64,8 \%$ \\
experimental periodontitis & 42 & $19,5 \%$ \\
periodontal plastic surgery & 19 & $8,8 \%$ \\
$\begin{array}{l}\text { pre-prosthetic surgery } \\
\text { Cirurgia Pré-protética }\end{array}$ & 4 & $1,9 \%$ \\
$\begin{array}{l}\text { surgical periodontal therapy } \\
\text { periapical therapy }\end{array}$ & 7 & $3,2 \%$ \\
$\begin{array}{l}\text { Interrelationship periodontics } \\
\text { and other specialties }\end{array}$ & 1 & $0,5 \%$ \\
peri-implant surgery & 2 & $0,5 \%$ \\
\hline \multicolumn{1}{c}{ Total } & $\mathbf{2 1 6}$ & $\mathbf{1 0 0} \%$ \\
\hline
\end{tabular}

The papers examined in the present study dealt with a wide range of topics among the field of Periodontics. Most of the papers published addressed issues related to basic periodontal therapies $(64.8 \%$ of all articles published at the 2017 meeting are linked to periodontics). This fact may be associated with a higher incidence of periodontal diseases and the constant need for improvement in the treatment of periodontal diseases in a less invasive manner and with less posttreatment sequelae for patients.

Thus, from what was collected and presented in this article, there's a need for considerable decentralization of Brazilian scientific production in periodontics, coupled with higher investments in research activities for regions farther away from the large centers. One limitation of this study is that it does not evaluate the number of papers published in its entirety in Brazil. Only the abstracts are published in annals of the SBPqO meetings, 
Table 5. Distribution of the works according to the type of research.

\begin{tabular}{c|c|c|}
\hline Type of research & Frequency & ( $\left.\mathbf{n}^{\circ} / \%\right)$ \\
\hline Observational Research & 92 & $42,6 \%$ \\
In Vivo Experimental Research & 86 & $39,8 \%$ \\
In Vitro Experimental Research & 17 & $7,9 \%$ \\
Bibliographic review & 13 & $6,0 \%$ \\
Ex vivo Experimental & 6 & $2,8 \%$ \\
$\quad$ Research & 6 & \\
$\quad \begin{array}{c}\text { In vivo and in vitro } \\
\text { Experimental Research }\end{array}$ & 2 & $0,9 \%$ \\
\hline Total & $\mathbf{2 1 6}$ & $\mathbf{1 0 0 \%}$ \\
\hline
\end{tabular}

hence this study cannot fully reflect the Brazilian scientific production in periodontics in the year evaluated. The authors make it clear that there are no conflicts of interest, either for political or financial motivation and they are not linked to any of the universities cited in this study, nor do they have any links with the SBPqO organization.

\section{CONCLUSION}

We found that the Southeast Region was responsible for more than half of all the country's scientific production in Periodontics in 2017. Public institutions, more expressively State-controlled ones, were the most productive ones on the subject, but only $48.6 \%$ of all published papers received some type of funding. Basic periodontal therapy was the area of Periodontics with the largest number of papers presented.

\section{CONFLICTS OF INTEREST}

The authors confirm no conflicts of interest. None of the authors are part of the mentioned universities, nor are they related to the scientific event cited in this study.

\section{CLINICAL RELEVANCE}

This study made a research about periodontics in Brazil. Main results: It aimed to report the monopoly of research and financing in some regions of Brazil. Practical consequences: Planning politics to encourage decentralization of research in Periodontics, as the creation of postgraduate courses in Periodontics outside of education centres in major cities.

\section{References}

1- Os desafios da pesquisa no Brasil. Caderno Temático. Jornal da Unicamp. 2002 Fev; (Suppl 1): 12.

2- Dias AA. Pesquisa odontológica no Brasil: características da produção científica no início do século XXI [Tese]. Natal (RN): UFRN; 2008.

3- Aquino SN et al. Produção científica odontológica e relação com agências de financiamento de pesquisa. Arq Odontol. 2009; 45:142-6.

4- Normando, D. The Brazilian dental science. Dental Press J. Orthod. 2014; 19, 14 5- Brasil. Ministério da Educação. Resolução $n^{\circ}$ CNE/CES 3/2002 de 19 de fevereiro de 2002. Institui as Diretrizes Curriculares Nacionais dos Cursos de Farmácia e Odontologia. Diário Oficial, Brasília, 04 mar 2002, seção 1, p. 10.

6- Xavier AFC, Silva ALO, Cavalcanti AL. Análise da produção científica em Odontologia no nordeste brasileiro com base em um congresso odontológico. Arq Odontol. 2011 Jul/Set; 47(3): 127-134.

7- Scariot, R., Stadler, A.F., Assunção, C.M., Pintarelli, T.P., Ferreira, F. de M. A map of Brazilian dental research in the last decade. Braz. Oral Res. 2011; 25: 197-204.

8- Araújo FL, Alvarenga L. A bibliometria na pesquisa científica da pós-graduação brasileira de 1987 a 2007. Enc Bibli: R Eletr Bibliotecon Ci Inf. 2011; 16(31):51-70.

9- Pinheiro RC, Pizzani L, Martinez CMS, Hayashi MCPI. Produção científica sobre avaliação da visão em crianças: um estudo bibliométrico na base de dados LILACS Rev Educ Esp. 2012; 25(42):143-66.
10- Pontes KT, Silva EL, Macedo Filho RA, SILVA DR, Lima FJ. Estudo bilbiométrico da produção científica em endodontia. Arch Health Invest. 2017; 6(9):435-438. 11- Cavalcanti AL, Melo TRNB, Barroso KMA, Souza FEC, Maia AMA, Silva ALO. Perfil da pesquisa científica em Odontologia realizada no Brasil. Pesq Bras Odontoped Clin Integr. 2004 Mai/Jun; 4 (2): 99-104.

12- Morosini IAC, Otto WB, Carneiro VL, Oliveira LLRV, Oliveira DC, Ferreira FM Profile of brazilian scientific research in pediatric dentistry based on the 26th annual meeting of the SBPqO. Rev Odonto Cienc. 2012; 27(2):132-136.

13- Conselho Federal de Odontologia. Consolidação das Normas para Procedimentos nos Conselhos de Odontologia. 2005. [acessado em 24/01/2018]. Disponível em: http://cfo.org.br/wp-content/uploads/2009/10/consolidacao.pdf

14- Cross, D., Thomson, S., Sinclair, A., n.d. Research in Brazil A report for CAPES by Clarivate Analytics [WWW Document]. URL https://www.capes.gov.br/images/ stories/download/diversos/17012018-CAPES-InCitesReport-Final.pdf (accessed 28.10.18)

15- Rocha FAC, Xavier RM. Da Relevância dos Estudos Observacionais. Rev Bras Reumatol. 2007; 47(2):01. 